\title{
Costs, benefits and characteristics of mixotrophy in marine oligotrichs
}

JOHN R. DOLAN*† and MARIA TERESA PÉREZ†

*Smithsonian Environmental Research Center, Edgewater, MD 21037, U.S.A.

+Marine Microbial Ecology Group, CNRS ESA 7076, Station Zoologique, B.P. 28, 06230 Villefranche-Sur-Mer, France

\section{SUMMARY}

1. Oligotrich ciliates are an important part of most marine plankton communities. Mixotrophic (chloroplast-sequestering) oligotrichs, a common component of marine oligotrich communities, obtain fixed carbon from both photosynthesis as well as the ingestion of particulate food. Mixotrophy, in general, is often considered an adaptation permitting exploitation of food-poor environments. We examined the hypothesis that, among oligotrichs, mixotrophs may be at a disadvantage relative to heterotrophs in food-rich conditions in a nutrient-enrichment experiment. We compared growth responses of mixotrophic and heterotrophic oligotrichs in natural communities from the N.W. Mediterranean Sea in microcosms with daily nutrient additions resulting in increases in nanoflagellates and Synechococcus populations. The results indicated that both mixotrophic and heterotrophic oligotrichs respond to prey increases with rapid growth $\left(\mu=1.2 \mathrm{~d}^{-1}\right)$.

2. To examine the hypothesis that the proportion of mixotrophic to heterotrophic oligotrichs changes with the trophic status of a system, increasing with oligotrophy, we examined data from a variety of marine systems. Across systems ranging in chlorophyll concentration from about 0.1 to $40 \mu \mathrm{g} \mathrm{L}^{-1}$, oligotrich cell concentrations are correlated with chlorophyll concentrations, and mixotrophs are a consistent component of oligotrich communities, averaging about $30 \%$ of oligotrich cell numbers.

3. We discuss the costs, benefits and possible uses of mixotrophy in marine oligotrichs and suggest that mixotrophy in marine oligotrichs is not closely linked to the exploitation of food-poor environments, but probably serves a variety of purposes.

Keywords: ciliates, heterotroph, marine oligotrichs, microzooplankton, mixotrophy

\section{Introduction}

Instinctively, we tend to divide organisms into two groups, plants and animals, separating those that use sunlight and photosynthesis, from those that consume or feed. However, these two trophic strategies, autotrophy and heterotrophy (literally, self-feeding and feeding from another), are two extremes of a continuum of strategies well illustrated among planktonic protists (e.g. Jones, 1994; Stoecker, 1998). Be-

Correspondence: John R. Dolan

E-mail: dolan@eerv.obs-vlfr.fr

(c) 2000 Blackwell Science Ltd tween photosynthesis, used by typical phytoplankters, and the herbivory or carnivory that characterizes most zooplankters, is 'mixotrophy', the combination of photosynthesis and the ingestion of particulate matter, phagotrophy. A wide range of different types of mixotrophy have been described in chloroplast-containing flagellates (e.g. Jones, 1997). Among marine flagellates, however, a common strategy appears to be one of generally relying on photosynthesis, but occasionally ingesting particulate matter to obtain either fixed carbon (under poor light conditions) or nutrients when these are scarce (e.g. Arenovski, Lim \& Caron, 1995; Bockstahler \& Coats, 1993; Christaki, Van Wambeke \& Dolan, 1999a; 
Havskum \& Riemann, 1996; Smalley, Coats \& Adam, 1999; Stoecker, 1999). Mixotrophy can also be found in organisms generally thought of as phagotrophic. Among sarcodines, many acantharians, radiolarians and foraminifera are predators of microzooplankton, but also harbour algal symbionts (Swanberg \& Caron, 1991); photosynthesis by the symbionts can provide a substantial part of the carbon requirement of the host-symbiont complexes (Caron et al., 1995).

Still another form of mixotrophy, involving a form of 'pseudo-symbiosis' chloroplast retention (see Laval-Peuto, 1992; Stoecker, 1991), is found among oligotrich ciliates common in the marine plankton. Many species of oligotrichs in the genera Tontonia, Laboea, and Strombidium sequester or enslave chloroplasts from ingested flagellates. The chloroplasts remain functional for periods ranging from hours to days, fixing carbon which is metabolized by the ciliate (Stoecker et al., 1988a\&b). The oligotrichs are mixotrophic because they also ingest and digest algal and non-algal prey as well as employ photosynthesis using captured chloroplasts. Chloroplasts, which do not reproduce inside the ciliate and therefore must be constantly replenished (Stoecker \& Silver, 1990), are retained from different types of algal prey and generally arranged around the cell perimeter (Laval-Peuto

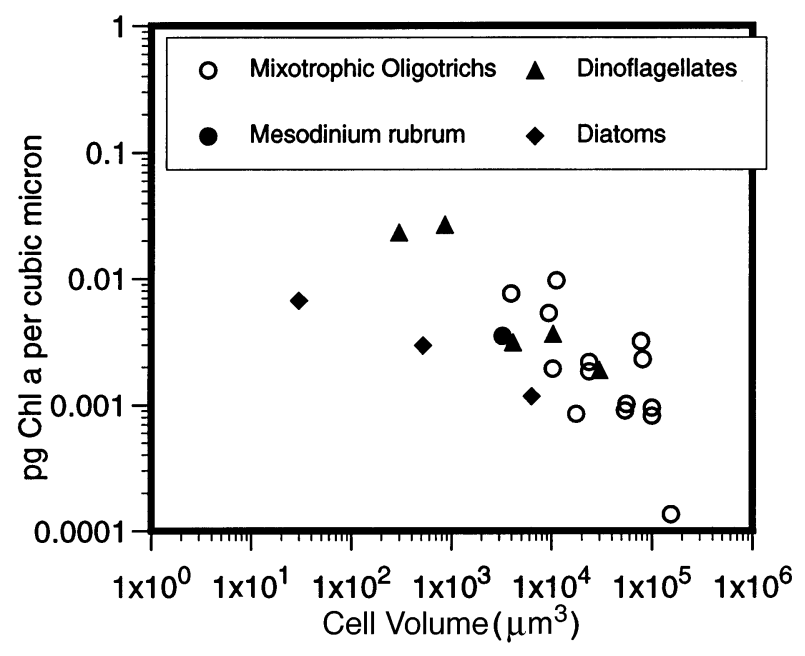

Fig. 1 Volume-specific chlorophyll content of marine mixotrophic oligotrichs (data from Petz, 1994; Putt, 1990a; Stoecker et al., 1987, 1989), the autotrophic ciliate Mesodinium rubrum Lohman (data from Stoecker et al., 1991) and various species of diatoms and dinoflagellates (data from Montagnes et al., 1994). Note that the volume-specific chlorophyll content of marine mixotrophic oligotrichs is similar to that of marine diatoms and dinoflagellates of similar size.
\& Febvre, 1986; Stoecker, 1992). The amount of chlorophyll contained in mixotrophic oligotrichs is comparable, on a per unit volume basis, to that found in diatoms and dinoflagellates of similar size (Fig. 1). The carbon fixed by the chloroplasts in mixotrophs has been found in the polysaccharide pool of the oligotrich (Putt, 1990a) and hourly photosynthetic rates may satisfy requirements for basal metabolism (Stoecker \& Michaels, 1991).

The type of mixotrophy found in marine oligotrichs, in which photosynthesis is apparently exploited primarily to cover respiratory demands, is thought to increase gross growth efficiency and resistance to starvation when food is scarce (Stoecker, 1998). Thus, it is an appealing notion that mixotrophy in marine oligotrichs evolved as a nutritional strategy that allows exploitation of oligotrophic or food-poor environments, as has been postulated with regard to sarcodines with symbiotic algae (e.g. Anderson, 1996; Norris, 1996). However, chloroplast-retaining (hereafter mixotrophic) oligotrichs are found in estuarine and marine systems ranging from eutrophic to very oligotrophic and even in oligotrophic systems, mixotrophs rarely dominate the ciliate community (Dolan, 1992). Beyond observations that they are rare below the euphotic zone and commoner in the spring and summer, little is known of factors regulating their abundance (Stoecker, 1991). The occurrence of mixotrophs in food-rich environments, as well as their incomplete dominance of oligotrophic communities, suggests that mixotrophy may involve benefits beyond allowing exploitation of oligotrophic waters and probably involves some costs.

From both theoretical and experimental approaches, cost-benefit analysis has been applied to phagotrophy in photoautotrophs, (e.g. Raven, 1997; Rothhaupt, 1996a\&b; Thingstad, 1996). However, such an analysis has not been attempted with regard to marine oligotrichs, excepting a preliminary effort by Pérez, Dolan \& Fukai (1997), who investigated copepod predation in field experiments and also compared maximum growth rates of mixotrophs and heterotrophs based on the reports in the literature. An unexpected potential benefit of mixotrophy was suggested because a mixotrophic oligotrich was consumed by copepods at a lower rate than a similarsized heterotrophic oligotrich. A cost associated with mixotrophy was estimated; following what one would predict after comparing growth rates of strict 
autotrophs and mixotrophic autotrophs (e.g. Raven, 1997), mixotrophic oligotrichs have lower maximum growth rates (approximately one-third of a generation per day) compared to similar-sized heterotrophic oligotrichs at a given temperature (Pérez et al., 1997).

Here we attempt to provide a more complete analysis of mixotrophy in marine oligotrichs. First, the growth responses of mixotrophic and heterotrophic oligotrichs to increases in food abundance, examined using an 'enrichment experiment' with a natural community is presented. Second, field distributions are examined with an eye towards establishing a general pattern of the abundance of mixotrophs relative to strictly heterotrophic oligotrichs and food abundance, roughly estimated as chlorophyll. Lastly, using our results and those from previous studies, we review the costs, benefits and characteristics of mixotrophic oligotrichs.

\section{Methods}

\section{Growth responses of oligotrichs to prey enrichment}

A microcosm experiment employing natural plankton communities from surface waters was performed in September 1997 using water collected from the entrance of Villefranche Bay (N.W. Mediterranean). Details of the experimental set-up and treatments, which were designed primarily to investigate the growth responses of bacteria, are given in Pérez (1998) and Thingstad et al. (1999). Briefly, duplicate 20-L translucent polyethylene carboys were filled with unfiltered surface water and assigned one of the following treatments of daily nutrient additions (to yield final concentrations) $-\mathrm{NO}_{3}$ only $(2 \mu \mathrm{M}), \mathrm{NO}_{3}+\mathrm{PO}_{4}(0.5 \mu \mathrm{M}), \mathrm{NO}_{3}+$ glucose $(10 \mu \mathrm{M})$, $\mathrm{NO}_{3}+\mathrm{PO}_{4}+$ glucose. The carboys were incubated on the pier of the Station Zoologique in a large, open, flow-through tank flushed with seawater pumped from a depth of $1 \mathrm{~m}$. Water temperature was approximately $26^{\circ} \mathrm{C}$.

Samples for determining the abundance of heterotrophic bacteria, Synechococcus, nanoflagellates and ciliates were removed daily over 6 days. We analysed the results here to examine the responses of different oligotrich types to increases in ciliate prey concentrations. Thus, we considered data only from those treatments that yielded a significant in- crease in the concentration of potential food for ciliates: microcosms with daily additions of $\mathrm{NO}_{3}+\mathrm{PO}_{4}$ and those that received $\mathrm{NO}_{3}, \mathrm{PO}_{4}$ and glucose.

Samples for counts of presumptive ciliate prey (Synechococcus, autotrophic and heterotrophic nanoflagellates) were fixed with $2 \% \mathrm{CaCO}_{3}$-buffered formalin ( $2 \%$ final conc.). For counts of Synechococcus, 10-mL aliquots were DAPI-stained (Porter \& Feig, 1980), drawn down onto $0.2-\mu \mathrm{m}$ pore-size black carbonate filters and mounted on slides. For flagellate counts, $0.8-\mu \mathrm{m}$ pore-size filters were employed. Slides were stored frozen at $-20^{\circ} \mathrm{C}$ until examination using a Zeiss Axiophot epifluorescence microscope. Organismal abundances were transformed into carbon units using a conversion factor

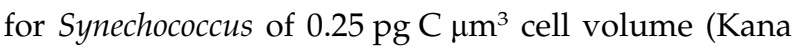
\& Glibert, 1987) for an average Synechococcus cell volume of about $0.5 \mu \mathrm{m}^{3}$, and for both autotrophic and heterotrophic nanoflagellates by applying the factor of $0.22 \mathrm{pg}$ carbon $\mu \mathrm{m}^{3}$ (Børsheim \& Bratbak, 1987) to an average flagellate cell volume of $65 \mu \mathrm{m}^{3}$.

For counting ciliates, aldehyde fixatives (which preserve chlorophyll fluorescence) are needed to establish trophic types, although such fixatives typically yield lower total cell counts compared to Lugol's (e.g. Stoecker et al., 1994). To circumvent this problem, parallel samples were fixed, one with $\mathrm{CaCO}_{3}$-buffered formalin ( $2 \%$ final concentration) and another with acid Lugol's (2\% final conc.). Fifty-millilitre aliquots of the formalin-fixed samples were settled and examined using an inverted Zeiss Axiophot epifluorescence microscope to determine the trophic category (mixotroph or heterotroph) of oligotrich ciliate morphotypes. Aliquots $(50 \mathrm{~mL})$ of the Lugol's fixed sample were settled and examined using transmitted light to determine the abundance of oligotrich ciliate morphotypes.

The growth rates of populations of mixotrophic and heterotrophic ciliates (pooled communities) were calculated assuming exponential growth over 5 periods: day $_{0}-$ day $_{1}$, day $_{1}-$ day $_{2}$, day $_{2}-$ day $_{3}$, day $_{3}-$ day $_{4}$, day $_{4}-$ day $_{5}$. Growth rates were then plotted against prey concentration (the aggregate concentration in terms of carbon of Synechococcus, autotrophic and heterotrophic nanoflagellates), estimated as the average of prey concentration at the beginning and end of the 24-h period over which growth rate was determined. 

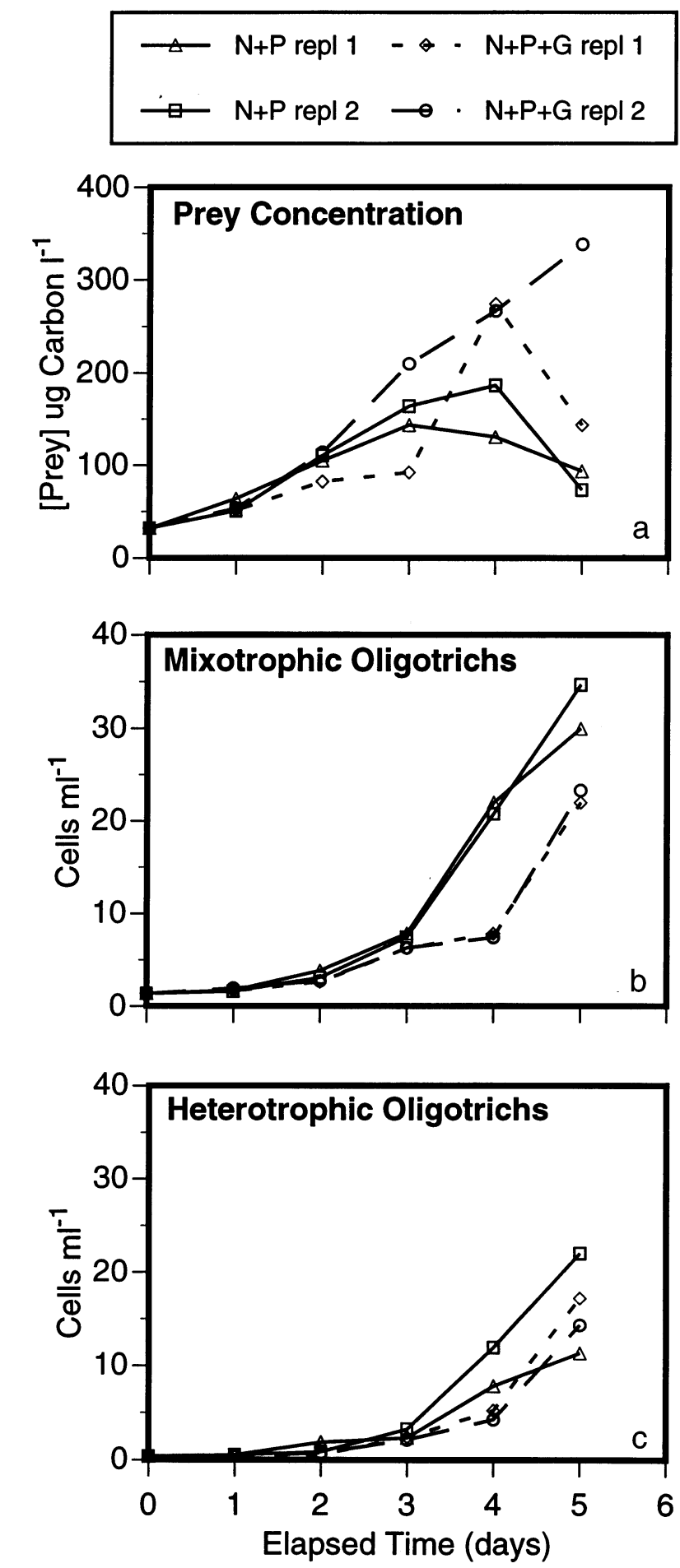

Fig. 2 Temporal changes in organismal concentrations in the four microcosms of the enrichment experiment. Two microcosms received daily additions of $\mathrm{NO}_{3}$ and $\mathrm{PO}_{4}(\mathrm{~N}+\mathrm{P}$ repl 1, N $+\mathrm{P}$ repl 2) and two microcosms received daily additions of $\mathrm{NO}_{3}$ and $\mathrm{PO}_{4}$ and glucose $(\mathrm{N}+\mathrm{P}+\mathrm{G}$ repl 1, $\mathrm{N}+\mathrm{P}+\mathrm{G}$ repl 2). Changes in presumptive ciliate prey concentration (a) in carbon units. Changes in concentration of mixotrophic oligotrichs (b) and heterotrophic oligotrichs (c).

\section{Field distributions}

To investigate the relationship between mixotrophic and heterotrophic oligotrich abundance across different marine systems, published reports providing data on mixotrophic and heterotrophic oligotrichs were assembled. Data on abundance in terms of cells per unit volume, rather than biomass, were collected. In contrast to cell concentration, which is directly estimated, biomass is a calculated variable, generally based on biovolumes which are subject to fixation artefacts and with mass units derived using diverse conversion factors. Furthermore, cell concentrations were reported more commonly. Where available, data on chlorophyll concentrations were also noted.

\section{Results}

Growth response of oligotrichs to prey enrichment

The mesocosms, which received daily nutrient additions, showed a marked increase in the abundance of presumptive oligotrich prey. In terms of carbon, potential prey for ciliates increased from $32 \mu \mathrm{g}$ carbon $\mathrm{L}^{-1}$ to peak values of $144-338 \mu \mathrm{g}$ carbon $\mathrm{L}^{-1}$ (Fig. 2a). Cyanobacterial concentration increased from $2.7 \times 10^{4}$ cells $\mathrm{mL}^{-1}$ at time 0 to a final concentration of $7 \times 10^{4}-1.9 \times 10^{5}$ cells $\mathrm{mL}^{-1}$. Autotrophic nanoflagellate populations grew from $6.8 \times 10^{2} \mathrm{~mL}^{-1}$ to $2.1-4.1 \times 10^{3}$ cells $\mathrm{mL}^{-1}$. Heterotrophic nanoflagellates increased from $1.4 \times 10^{3}$ cells $\mathrm{mL}^{-1}$ to peak values of $5.1 \times 10^{3}-1.1 \times 10^{4}$ cells $\mathrm{mL}^{-1}$. Throughout the experiment, Synechococcus represented a relatively minor component of potential prey for ciliates $(<$ $15 \%)$ in terms of carbon; autotrophic and heterotrophic nanoflagellates contributed approximately equal proportions of presumed prey.

The concentration of oligotrichs increased concomitantly with nanoflagellate and Synechococcus populations. The community of mixotrophic oligotrichs, almost entirely composed of a single $30-\mu \mathrm{m}$ diameter Strombidium sp., increased from 1.4 cells $\mathrm{mL}^{-1}$ at time 0 to a concentration of $22-34.7$ cells $\mathrm{mL}^{-1}$ at day 5 (Fig. 2b). Heterotrophic oligotrichs, dominated by small 25-30- $\mu \mathrm{m}$ Strombidium spp., increased from 0.38 cells $\mathrm{mL}^{-1}$ to final concentrations of $11.3-22$ cells $\mathrm{mL}^{-1}$ (Fig. 2c).

Community growth rate varied widely, of both mixotrophic oligotrichs $\left(0.16-1.14 \mathrm{~d}^{-1}\right)$ and heterotrophic oligotrichs $\left(0-1.46 \mathrm{~d}^{-1}\right)$. However, growth 
rate generally increased with prey concentration (Fig. 3a). The pattern of increasing growth rate with prey concentration was clear, with no difference between mixotrophs and heterotrophs, when growth rate was divided into four groups corresponding to a prey concentration of approximately 50, 100, 200 and $300 \mu \mathrm{g}$ carbon $\mathrm{L}^{-1}$ and mean rate plotted against prey concentration (Fig. 3b).

\section{Field distributions}

Comparing oligotrich abundance across systems revealed a very large range of reported concentrations (Table 1). However, total (mixotrophic + heterotrophic) oligotrich abundance was well correlated with chlorophyll concentration (Fig. 4a). Mixotrophic oligotrich concentration appeared strongly related to heterotrophic oligotrich abundance (Fig. 4b). Considering the two groups separately, there was little evi-
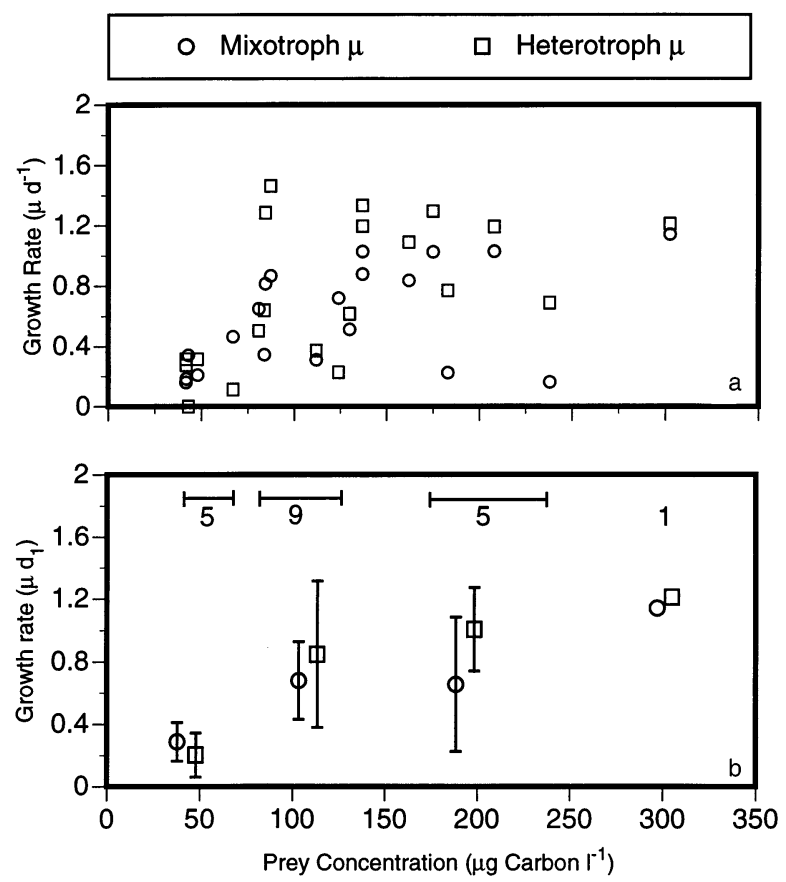

Fig. 3 Calculated growth rate of mixotrophic and heterotrophic oligotrichs in the enrichment experiment microcosms. Mixotrophic and heterotrophic oligotrich growth rate plotted as a function of the average quantity of ciliate prey available in the $24 \mathrm{~h}$ period over which growth was calculated. The top panel (a) shows individual data points. The bottom panel (b) presents growth rates pooled into four sets; the lines indicate the range through which rates were pooled; the number indicates the number of rates pooled within the set, error bars represent SD.

(C) 2000 Blackwell Science Ltd, Freshwater Biology, 45, 227-238 dence that mixotrophic oligotrichs were more abundant, relative to heterotrophic oligotrichs, in systems with low chlorophyll concentration, nor did the two oligotrich types appear to display different relationships of abundance as a function of chlorophyll (Fig. 4c).

\section{Discussion}

In our experiment with a natural planktonic community, in which nutrient additions yielded increases in food concentration, mixotrophic and heterotrophic oligotrichs reacted in a very similar manner in terms of net community growth rate (Fig. 3a,b). Such results suggest that mixotrophic oligotrichs can grow at a rate similar to their heterotrophic counterparts at a given food concentration. However, two major caveats should be considered. Firstly, mortality rates were not measured and could have differed between mixotrophs and heterotrophs. For example, data from a previous study led to the suggestion that heterotrophic oligotrichs may be ingested by copepods at a higher rate than are mixotrophic oligotrichs (Pérez et al., 1997) and copepods were present in the mesocosms, at a concentration of about $10 \mathrm{~L}^{-1}$ (all postnaupliar stages combined), based on their abundance in settled samples. Thus, heterotrophic oligotrich growth rates may have been relatively underestimated. Secondly, the growth rates estimated were transient responses to transient increases in prey concentration. Had prey concentrations been maintained over several ciliate generations, differences may have appeared. The caveats notwithstanding, our data show that mixotrophic oligotrichs, while displaying a lower maximum growth rate (Pérez et al., 1997), are capable of responding to rapid increases in food availability much like their heterotrophic congeners.

The analysis of reports giving the field abundance of different types of oligotrichs in a large variety of marine and estuarine systems yielded some expected as well as unexpected relationships. The correlation between the concentration of total oligotrichs and chlorophyll $a$ (Fig. 4a) echoed earlier findings of a correlation between the biomass of ciliates and phytoplankton in marine systems (Lynn \& Montagnes, 1991), as well as the correlation of ciliate biomass and chlorophyll $a$ concentration in open water marine systems (Dolan, Vidussi \& Claustre, 1999). Unexpectedly, there was little evidence of an increase in con- 
Table 1 Abundance of oligotrichs from reports that distinguished mixotrophic and heterotrophic oligotrichs. Mixotroph abundances denoted with '*' are probably underestimates as the figures consist only of the abundances of mixotrophs recognized via distinctive characteristics of gross morphology (e.g. Laboea strobila, Tontonia spp.) rather than direct observation of all oligotrichs with chloroplasts

Oligotrich abundance (cells $\mathrm{L}^{-1}$ )

\begin{tabular}{|c|c|c|c|c|c|c|}
\hline & \multirow[b]{2}{*}{$\begin{array}{l}\text { Period } \\
\text { sampled }\end{array}$} & \multirow[b]{2}{*}{$\begin{array}{l}\text { Depth interval } \\
\text { sampled (m) }\end{array}$} & & \multirow[b]{2}{*}{ Chl $a\left(\mu \mathrm{g} \mathrm{L}^{-1}\right)$} \\
\hline Study site & Reference & & & Mixotroph & Heterotrophic & \\
\hline \multicolumn{7}{|l|}{ Atlantic } \\
\hline Iceland Sea & Putt, 1990a & July & 0 & 428 & 255 & 0.8 \\
\hline Barents Sea & Putt, 1990a & August & 0 & 318 & 230 & 0.2 \\
\hline North Atlantic & Stoecker et al., 1994 & May 1989 & $0-20$ & 3006 & 1112 & 3 \\
\hline North Atlantic & Stoecker et al., 1994 & May/June 1990 & $0-20$ & 1364 & 909 & 2.4 \\
\hline Georges Bank & Stoecker et al., 1989 & July & $0-36$ & 1014 & 1499 & 0.9 \\
\hline $\begin{array}{l}\text { U.S.A. (MA) } \\
\text { coastal }\end{array}$ & Stoecker et al., 1987 & July & $0-9$ & 2380 & 723 & $\mathrm{Nd}$ \\
\hline $\begin{array}{l}\text { U.S.A. (MD) } \\
\text { coastal }\end{array}$ & Dolan, 1988 & Apr-Dec & $0-5$ & $19^{*}$ & 4657 & 12.3 \\
\hline $\begin{array}{l}\text { U.S.A. (MD) } \\
\text { coastal }\end{array}$ & $\begin{array}{l}\text { Dolan \& Gallegos, } \\
\text { 1992; unpub. obs. }\end{array}$ & Mar-Sept & 0 & 3358 & 14220 & 40.7 \\
\hline $\begin{array}{r}\text { Bermuda } \\
\text { coastal }\end{array}$ & $\begin{array}{l}\text { Lynn, Roff \& } \\
\text { Hopcroft, } 1991\end{array}$ & 1 year & 5 & $36^{*}$ & 206 & $\mathrm{Nd}$ \\
\hline $\begin{array}{c}\text { Southern } \\
\text { Ocean }\end{array}$ & $\begin{array}{l}\text { Froneman \& } \\
\text { Perissinotto, } 1996\end{array}$ & June/July & 5 & 5.8 & 86.4 & 0.5 \\
\hline \multicolumn{7}{|l|}{ Pacific } \\
\hline $\begin{array}{c}\text { Subarctic } \\
\text { Pacific }\end{array}$ & $\begin{array}{l}\text { Suzuki, Yamada \& } \\
\text { Taniguchi, } 1998\end{array}$ & June & $0-50$ & 233 & 985 & 0.6 \\
\hline $\begin{array}{c}\text { Subarctic } \\
\text { Pacific }\end{array}$ & Suzuki et al., 1998 & Oct/Nov & $0-50$ & 60 & 445 & 0.8 \\
\hline $\begin{array}{l}\text { Subtrop. } \\
\text { Pacific }\end{array}$ & Suzuki et al., 1998 & October & $0-50$ & 103.5 & 115 & 0.2 \\
\hline $\begin{array}{l}\text { CAN (BC) } \\
\text { coastal }\end{array}$ & $\begin{array}{l}\text { Martin \& Montagnes, } \\
1993\end{array}$ & Feb & 2 & $58^{*}$ & 2372 & 2.2 \\
\hline Eq. Pacific & $\begin{array}{l}\text { Stoecker, Gustafson \& } \\
\text { Verity, } 1996\end{array}$ & April & $0-120$ & 4.5 & 39.5 & $\mathrm{Nd}$ \\
\hline Eq. Pacific & Stoecker et al., 1996 & October & $0-120$ & 1.8 & 67.7 & $\mathrm{Nd}$ \\
\hline \multicolumn{7}{|l|}{ Mediterranean } \\
\hline Ligurian Sea & Pérez et al., 2000 & May & $5-50$ & 1120 & 1314 & 0.5 \\
\hline Blanes Bay & Vaqué et al., 1997 & 3 years & 0.5 & 417 & 1884 & 1 \\
\hline Catalan Sea & Dolan \& Marrasé, 1995 & June & $0-80$ & $24^{*}$ & 376 & 0.4 \\
\hline Western Med. & Dolan et al., 1999 & May & $5-90$ & $47^{*}$ & 677 & 0.1 \\
\hline Central Med. & Dolan et al., 1999 & May & $5-105$ & $64^{*}$ & 544 & 0.2 \\
\hline Eastern Med. & Dolan et al., 1999 & May & $5-130$ & $39^{*}$ & 330 & 0.1 \\
\hline
\end{tabular}

centration of mixotrophs relative to heterotrophs in low chlorophyll waters (Fig. 4b). However, it should be noted that chlorophyll $a$ concentration is probably only a rough estimate of oligotrich food stocks. Mixotrophic and heterotrophic oligotrichs appear well-correlated across a very wide range of abundance, with mixotrophs representing on average about $30 \%$ of oligotrich numbers (Fig. 4c). A similar value of about $30 \%$ of total oligotrichs as mixotrophs was reported in a comparison of oligotrich communi- ties in transects across shelf and slope waters of the N.E. coastal USA (Stoecker, Taniguchi \& Michaels, 1989).

Within individual systems, mixotrophic oligotrichs have often been reported to represent highly variable proportions of the oligotrich community, both temporally (e.g. Bernard \& Rassoulzadegan, 1994; Stoecker, Michaels \& Davis, 1987; Laval-Peuto \& Rassoulzadegan, 1988; Vaqué, Blough \& Duarte, 1997) and spatially (e.g. Dolan \& Marrasé, 1995; Dolan et al., 1999). 
The relationships we describe result from a cross-system analysis of data averaged over different temporal
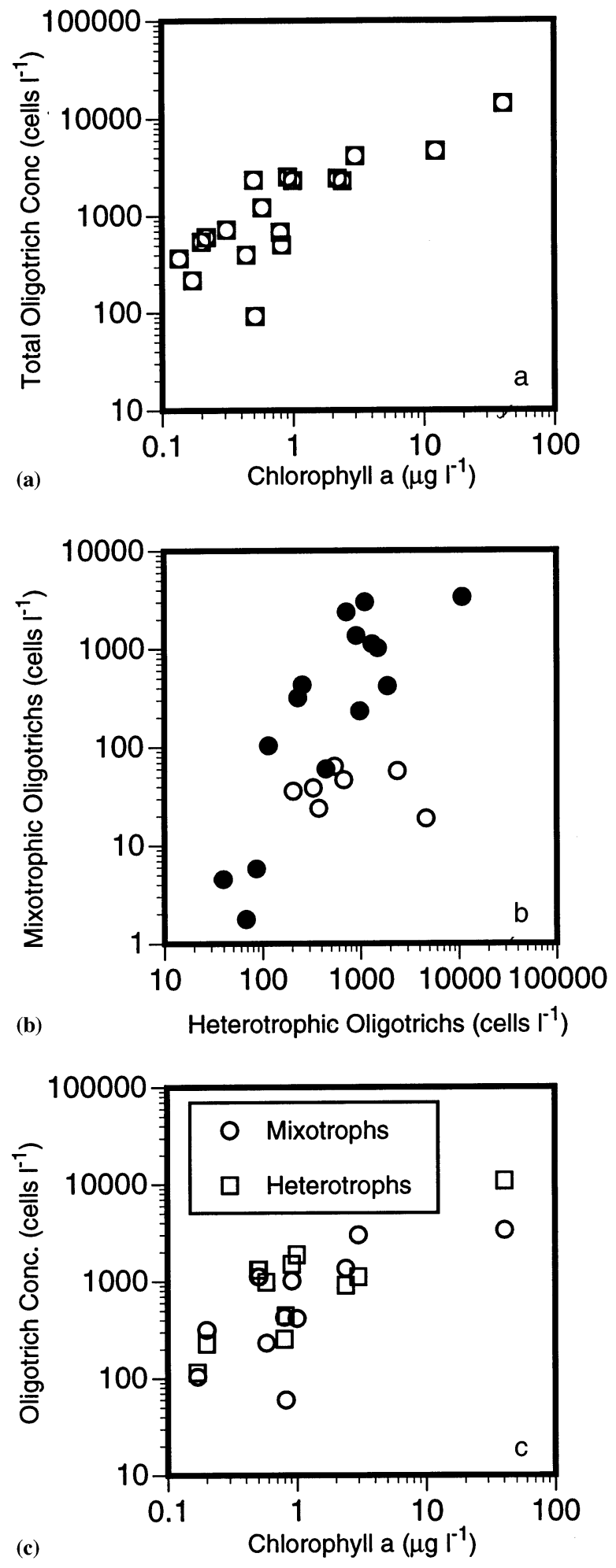

Fig. 4. and spatial scales. While such a treatment involves a good deal of data averaging, it nonetheless appears that mixotrophic oligotrichs are a consistent and generally minor component of oligotrich communities across systems. Below, we review the costs and benefits and possible phenomena associated with mixotrophy in an attempt to provide an explanation for their apparently consistent occurrence in diverse marine systems.

\section{Costs and benefits of mixotrophy}

Costs. Few of the costs involved with mixotrophy in marine oligotrichs have been identified with certainty hitherto. Mixotrophs are generally restricted to the euphotic zone (Stoecker, 1998), where most of the biomass of planktonic ciliates is usually found (e.g. Dolan \& Marrasé, 1995). Maximum potential growth rate may be lower in mixotrophic relative to heterotrophic oligotrichs, but only by about a third of a generation per day (Pérez et al., 1997), and ciliates rarely achieve their maximum potential growth rate under in situ conditions. Our data from the enrichment experiment suggest that mixotrophic oligotrichs are capable of responding to increased food availability with rapid growth, as are heterotrophic oligotrichs.

A possible cost involved with mixotrophy, an increased vulnerability to starvation during prolonged darkness $(>12 \mathrm{~h})$, was revealed in a study of dark

Fig. 4 Results of a cross-system analysis of oligotrich abundance patterns based on data given in Table 1. Using log-transformed data, the abundance of total oligotrichs (mixotrophs and heterotrophs) was correlated with chlorophyll concentration (a) $r^{2}=0.656, P=0.0001, n=18$, $\log Y=3.084+0.675 \times \log X$. Mixotrophic oligotrich concentration was related to the abundance of heterotrophic oligotrichs (b) $r^{2}=0.705, P=0.0001, n=15, \log$ $Y=-1.298+1.354 \times \log X$; for this analysis, reports were omitted which only gave abundances of morphologically distinct mixotrophs (open circles) rather than all chloroplast-containing oligotrichs (filled circles). Pooling data from the small number of reports $(n=12)$ giving abundances of all chloroplast-containing oligotrichs, heterotrophic oligotrichs and chlorophyll concentration (c) yielded significant relationships between mixotrophic abundance and chlorophyll $\left(r^{2}=0.345, P=0.0448, \log Y=2.572+0.744 \times \log \right.$ $X)$, as well as heterotrophic oligotrichs and chlorophyll $\left(r^{2}=0.627, P=0.0021, \log Y=2.834+0.751 \times \log X\right)$. Note the similar slopes of the abundance as a function of chlorophyll relationships for the two oligotrich types. 
respiration in the mixotroph Strombidium capitatum Leegard (Crawford \& Stoecker, 1996). Compared to a similar-sized heterotrophic oligotrich, the mixotroph displayed a higher cell-carbon specific rate of respiration (Crawford \& Stoecker, 1996). The physiological explanation for such a phenomenon is unclear, but may partly explain the restriction of mixotrophs to the euphotic zone.

Another potential cost involved with mixotrophy may be that of selective feeding. Selective feeding is well known among heterotrophic ciliates (e.g. Christaki et al., 1998, 1999b; Stoecker, 1988; Verity, 1991a). Mixotrophs apparently require, and may selectively ingest, prey items with chloroplasts. Selective feeders can be at a disadvantage relative to non-selective feeders under a variety of conditions; for example, when preferred prey are low in concentration (see Sierszen \& Frost, 1992).

There are limited data on feeding behaviour in mixotrophic, compared to heterotrophic, oligotrichs. The general feeding parameters of clearance rate and the size-spectrum of particles retained appear similar in mixotrophic and heterotrophic oligotrichs (Jonsson, 1987). However, some indications of selective feeding were found in a study of the mixotrophic Strombidium reticulatum Leegard and the heterotrophic Lohmanniella spiralis Leegard offered micro-

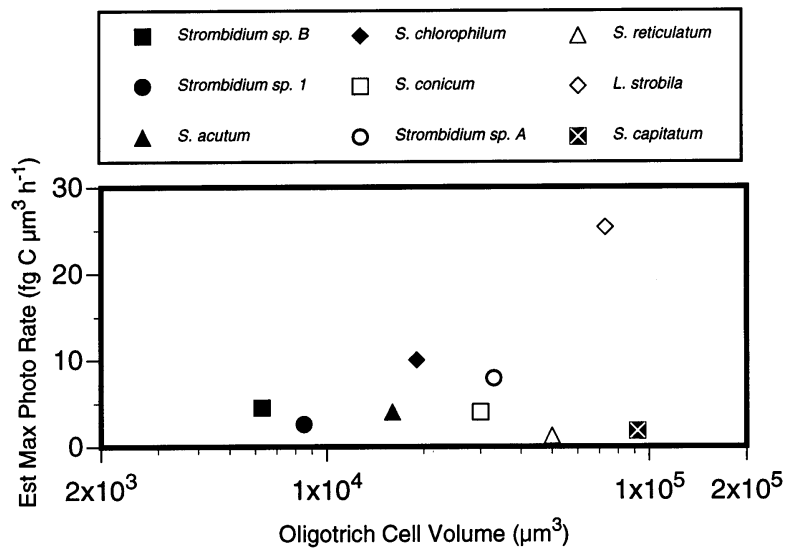

Fig. 5 Maximum reported photosynthetic rates of mixotrophic oligotrichs: volume-specific rates as a function of cell volume. Data from Jonsson, (1987), Putt, (1990b), Stoecker \& Michaels, (1991), Stoecker et al., (1988a \& 1989). With the exception of Laboea strobila Lohman, volume-specific rates appear relatively constant and independent of cell size across a large range of cell volumes. Note, however, that while these rates are the maximum reported, they may be less than the rate of photosynthesis under light saturating conditions (Pmax). spheres and similar-sized algal prey; unlike the heterotroph, the mixotroph displayed a higher clearance rate on algal prey (Jonsson, 1986). While such selection may appear advantageous for oligotrichs offered algal and inert prey items, if algal prey is scarce and preferred over equally abundant non-algal prey (i.e. heterotrophic nanoflagellates), selective feeding could be costly.

The evidence that exists from the field suggests that mixotrophic oligotrichs may feed selectively on algal prey. Working with natural populations of the mixotroph, Tontonia appendiculariformis FauréFremiet, Laval-Peuto et al. (1986) analysed food vacuole contents using transmission electron microscopy. Their study of oligotrichs collected from Villefranche Bay revealed that a variety of autotrophic flagellates (with chloroplasts similar to those sequestered) were found in found in food vacuoles, but heterotrophic nanoflagellates were rare (Laval-Peuto et al., 1986), despite the fact that heterotrophic nanoflagellates are generally as abundant as autotrophic flagellates in the bay (e.g. Ferrier-Pagès \& Rassoulzadegan, 1994). Aggregation behaviour, in the presence of different algal prey items, has also been compared for mixotrophs and heterotrophs from natural populations; mixotrophic oligotrichs appeared to be more consistently attracted to dinoflagellate prey than heterotrophic oligotrichs (Verity, 1991b).

Benefits. The benefit of photosynthesis in mixotrophic oligotrichs (the fixation of inorganic carbon) has been quantified in several species. All oligotrichs examined with sequestered chloroplasts fix inorganic carbon. Mixotrophs then profit from photosynthesis, allowing exploitation of habitats with absolute low particulate prey concentrations and/or habitats in which prey are not necessarily scarce overall but patchy in time and space.

The quantity of carbon fixed has been estimated to be about sufficient to satisfy basal metabolism (Jonsson, 1987; Stoecker et al., 1987, 1988a; Stoecker \& Michaels, 1991). However, a wide range of photosynthetic rates has been reported. Considering experiments conducted under light conditions of near-saturating intensity for most autotrophic flagellates $\left(=200 \mu \mathrm{E} \mathrm{m}^{2} \mathrm{sec}^{-1}\right.$ ), the rate of carbon fixation appears more or less independent of oligotrich size and averages about $5 \mathrm{fg}$ carbon $\mu \mathrm{m}^{3}$ oligotrich cell volume $\mathrm{h}^{-1}$ (Fig. 5). If the volume-specific rate of 
photosynthesis is about the same in oligotrichs of different sizes, there is probably a large gradient among mixotrophic oligotrichs in the benefit derived or relative importance of photosynthesis compared to heterotrophic nutrition. As the volume-specific respiration rate decreases with increasing cell size (e.g. Fenchel \& Finlay, 1983), larger mixotrophic oligotrichs may be more autotrophic than small mixotrophic oligotrichs. That is, carbon fixed via photosynthesis may be a larger proportion of the carbon respired in large compared to small mixotrophic oligotrichs. One might predict that the assemblage of mixotrophic oligotrichs found in eutrophic systems could differ from that found in oligotrophic systems with the larger, 'more autotrophic' mixotrophs being commoner in oligotrophic systems.

The products of photosynthesis may also be put to a variety of uses in mixotrophic oligotrichs. Although not all mixotrophs display unusual behaviour, mixotrophy in some species may permit (or subsidize) energetically expensive, but predation-resistant, swimming patterns or escape responses, as is thought to be the case for the autotrophic ciliate Mesodinium rubrum Lohman (Crawford, 1992). This hypothesis was invoked to explain the low rate of copepod predation on a mixotrophic oligotrich compared to that on a similar-sized heterotrophic oligotrich (Pérez et al., 1997). It should be noted that we are not attempting to correlate mixotrophy with predation resistance, since anti-predator behaviour and morphology are found among heterotrophic ciliates.

Mixotrophy may also subsidize energetically costly life-history stages such as cysts. Clearly mixotrophy is not a prerequisite for cyst formation, as it is relatively common among tintinnid ciliates, all of which are heterotrophic. Neither is cyst formation an obligatory life-history stage of mixotrophic oligotrichs, as several species have been cultured with no mention of encystment. However, all marine oligotrichs known to form cysts have hitherto been reported to be mixotrophic: Strombidium conicum Lohman (Kim \& Taniguchi, 1995, 1997), Strombidium oculatum Gruber (Jonsson, 1994) and, perhaps, Strombidium crassulum Leegard [provisionally identified as such by Reid, (1987), but see Müller, (1996)].

Marine mixotrophic oligotrichs can be characterized as a very common and consistent, if rarely dominant, component of planktonic ciliate communities, much like tintinnid ciliates. The benefits of mixotro- phy probably vary among mixotrophic species, perhaps as a function of cell size, and rather than simply allowing exploitation of food-poor environments, the benefits probably serve a variety of purposes. The costs of mixotrophy identified hitherto do not appear severe and prompt the question as to why mixotrophic oligotrichs rarely dominate marine ciliate communities.

\section{Acknowledgments}

Financial support was provided by the CNRS, the Commission of the European Communities through the contract MEDEA (MAS3 CT95-0016), a Eusko Jaurlaritza (Basque government) grant to M.T.P. and the Smithsonian Office of Fellowships and Grants. A portion of the work reported here (the enrichment experiment) is part of the doctoral dissertation of M.T.P. Helga Müller and an anonymous reviewer provided valuable criticism of an earlier version of this paper.

\section{References}

Anderson O.R. (1996) The physiological ecology of planktonic sarcodines with applications to paleoecology: patterns in space and time. Journal of Eukaryotic Microbiology, 43, 261-274.

Arenovski A.L., Lim E.L. \& Caron D.A. (1995) Mixotrophic nanoplankton in oligotrophic surface waters of the Sargasso Sea may employ phagotrophy to obtain major nutrients. Journal of Plankton Research, 17, 801-820.

Bernard C. \& Rassoulzadegan F. (1994) Seasonal variations of mixotrophic ciliates in the northwest Mediterranean Sea. Marine Ecology Progress Series, 108, 295-301.

Bockstahler K.R. \& Coats D.W. (1993) Grazing of the mixotrophic dinoflagellate Gymnodinium sanguineum on ciliate populations of Chesapeake Bay. Marine Biology, 116, 477-487.

Børsheim K.Y. \& Bratbak G. (1987) Cell volume to cell carbon conversion factors for a bactivorous Monas sp. enriched from seawater. Marine Ecology Progress Series, 36, 171-175.

Caron D., Michaels A.F., Swanberg N.R. \& Howse F.A. (1995) Primary production by symbiont-bearing planktonic sarcodines (Acantharia, Radiolaria, Formanifera) in surface waters near Bermuda. Jour nal of Plankton Research, 17, 103-129. 
Christaki U., Dolan J.R., Pelegri S. \& Rassoulzadegan F. (1998) Consumption of picoplankton-size particles by marine ciliates: effects of physiological state of the ciliate and particle quality. Limnology and Oceanography, 43, 458-464.

Christaki U., Van Wambeke F. \& Dolan J.R. (1999a) Nanoflagellates (mixotrophs, heterotrophs \& autotrophs) in the oligotrophic eastern Mediterranean: standing stocks, bacterivory and relationships with bacteria production. Marine Ecology Progress Series, 181, 297-307.

Christaki U., Jacquet S., Dolan J.R., Vaulot D. \& Rassoulzadegan F. (1999b) Growth and grazing on Prochlorococcus and Synechococcus by two marine ciliates. Limnology and Oceanography, 44, 52-61.

Crawford D.W. (1992) Metabolic costs of motility in planktonic protists: theoretical considerations on size scaling and swimming speed. Microbial Ecology, 24, 1-10.

Crawford D.W. \& Stoecker D.K. (1996) Carbon content, dark respiration and mortality of the mixotrophic planktonic ciliate Strombidium capitatum. Marine Biology, 126, 415-422.

Dolan J.R. (1988) The ecology of ciliate microzooplankton in the Chesapeake Bay. Ph.D. thesis, University of Maryland, Maryland, USA.

Dolan J.R. (1992) Mixotrophy in ciliates: a review of chlorella symbiosis and chloroplast retention. Marine Microbial Food Webs, 6, 115-132.

Dolan J.R. \& Gallegos C.C. (1992) Trophic role of planktonic rotifers in the Rhode River Estuary, spring-summer 1991. Marine Ecology Progress Series, 85, 187-199.

Dolan J.R. \& Marrasé C. (1995) Planktonic ciliate distribution relative to a deep chlorophyll maximum: Catalan Sea, N.W. Mediterranean, June 1993. Deep-Sea Research I, 42, 1965-1987.

Dolan J.R., Vidussi F. \& Claustre H. (1999) Planktonic ciliates in the Mediterranean Sea: longitudinal trends. Deep-Sea Research I, 46, 2025-2039.

Fenchel T. \& Finlay B.J. (1983) Respiration rates in heterotrophic free-living protozoa. Microbial Ecology, 24, 307-322.

Ferrier-Pagès C. \& Rassoulzadegan F. (1994) Seasonal impact of the microzooplankton on pico- and nanoplankton growth rates in the northwest Mediterranean Sea. Marine Ecology Progress Series, 108, 283-294.
Froneman P.W. \& Perissinotto R. (1996) Structure and grazing of the microzooplankton communities of the subtropical convergence and a warm core eddy in the Atlantic sector of the southern ocean. Marine Ecology Progress Series, 135, 237-245.

Havskum H. \& Riemann B. (1996) Ecological importance of bacterivorous, pigmented flagellates (mixotrophs) in the Bay of Aarhus, Denmark. Marine Ecology Progress Series, 137, 251-263.

Jones H.L.J. (1997) A classification of mixotrophic protists based on their behaviour. Freshwater Biology, 37, 35-43.

Jones R.I. (1994) Mixotrophy in planktonic protists as a spectrum of nutritional strategies. Marine Microbial Food Webs, 8, 87-96.

Jonsson P.R. (1986) Particle size selection, feeding rates and growth dynamics of marine planktonic oligotrichious ciliates (Ciliophora, Oligotrichina). Marine Ecology Progress Series, 33, 265-277.

Jonsson P.R. (1987) Photosynthetic assimilation of inorganic carbon in marine oligotrich ciliates (Ciliophora, Oligotrichina). Marine Microbial Food Webs, 2, 55-68.

Jonsson P.R. (1994) Tidal rhythm of cyst formation in the rock pool ciliate Strombidium oculatum Gruber (Ciliophora, Oligotrichida): a description of the functional biology and an analysis of the tidal synchronization of encystment. Journal Experimental Marine Biology and Ecology, 175, 77-103.

Kana T. \& Glibert P. (1987) Effects of irradiances up to $2000 \mu \mathrm{E} \mathrm{m}^{-2} \mathrm{~s}^{-1}$ on marine Synechococcus $\mathrm{WH}$ 7803-I. Growth, pigmentation and cell composition. Deep-Sea Research, 34, 479-516.

Kim Y.-O. \& Taniguchi A. (1995) Excystment of the oligotrigh ciliate Strombidium conicum. Aquatic Microbial Ecology, 9, 149-156.

Kim Y.-O. \& Taniguchi A. (1997) Seasonal variation of excystment pattern of the planktonic oligotrich Strombidium conicum. Marine Biology, 128, 207-212.

Laval-Peuto M. (1992) Plastidic protozoa. In: Algae and Symbiosis (ed. W. Reisser), pp. 471-499. Biopress Ltd., Bristiol, UK.

Laval-Peuto M. \& Febvre M. (1986) On plastid symbiosis in Tontonia appendiculariformis (Ciliophora, Oligotrichina). BioSystems, 19, 137-158.

Laval-Peuto M. \& Rassoulzadegan F. (1988) Autofluorescence of marine planktonic Oligotrichina and other ciliates. Hydrobiologia, 159, 99110.

(C) 2000 Blackwell Science Ltd, Freshwater Biology, 45, 227-238 
Laval-Peuto M., Salvano P., Gayol P. \& Greuet C. (1986) Mixotrophy in marine planktonic ciliates: ultrastructural study of Tontonia appendiculariformis (Ciliophora, Oligotrichina). Marine Microbial Food Webs, 1, 81-104.

Lynn D.H. \& Montagnes D.J.S. (1991) Global production of heterotrophic marine planktonic ciliates. In: Protozoa And Their Role In Marine Processes (eds P.C. Reid, C.M. Turley \& P.H. Burkill), pp. 281-307. Springer-Verlag, Berlin.

Lynn D.H., Roff J.C. \& Hopcroft R.R. (1991) Annual abundance and biomass of aloricate ciliates in tropical neritic waters of Kingston, Jamaica. Marine Biology, 110, 437-448.

Martin A.J. \& Montagnes D.J.S. (1993) Winter ciliates in a British Columbia fjord: six new species and an analysis of ciliate putative prey. Journal of Eukaryotic Microbiology, 40, 535-549.

Montagnes D.J.S., Berges J.A., Harrison P.J. \& Taylor F.J.R. (1994) Estimating carbon, nitrogen, protein and chlorophyll $a$ from volume in marine phytoplankton. Limnology and Oceanography, 39, 10441060.

Müller H. (1996) Encystement of the freshwater ciliate Pelagostrombidium fallax (Ciliophora, Oligotrichida) in laboratory culture. Aquatic Microbial Ecology, 11, 289-295.

Norris R.D. (1996) Symbiosis as an evolutionary innovation in the radiation of Paleocene planctic foraminifera. Paleobiology, 22, 461-480.

Pérez M.T. (1998) Relations trophiques au sein du réseau microbien en Méditerranée nord-occidentale: importance de la predation et des ressources. Ph.D. thesis, Université de Pierre et Marie Curie (Paris $V I)$.

Pérez M.T., Dolan J.R. \& Fukai E. (1997) Planktonic oligotrich ciliates in the NW Mediterranean: growth rates and consumption by copepods. Marine Ecology Progress Series, 155, 89-101.

Pérez M.T., Dolan JR., Vidussi F. \& Fukai E. (2000) Diel vertical distribution of planktonic ciliates within the surface layer of the NW Mediterranean (May 1995). Deep-Sea Research I, 47, 479-503.

Petz W. (1994) Morphology and morphogenesis of Strombidium krylais nov. spec. (Ciliophora, Strombidiida) from Anarctic Sea ice. Archiv für Protistenkunde, 144, 185-195.

(C) 2000 Blackwell Science Ltd, Freshwater Biology, 45, 227-238
Porter K.G. \& Feig Y.S. (1980) The use of DAPI for identifying and counting aquatic microflora. Limnology and Oceanography, 25, 943-948.

Putt M. (1990a) Abundance, chlorophyll content and photosynthetic rates of ciliates in the Nordic Seas during summer. Deep-Sea Research, 37, 1713-1731.

Putt M. (1990b) Metabolism of photosynthate in the chloroplast-retaining ciliate Laboea strobila. Marine Ecology Progress Series, 60, 271-282.

Raven J.A. (1997) Phagotrophy in phototrophs. Limnology and Oceanography, 42, 198-205.

Reid P.C. (1987) Mass encystment of a planktonic oligotrich ciliate. Marine Biology, 95, 221-230.

Rothhaupt K.O. (1996a) Utilization of substitutable carbon and phosphorous sources by the mixotrophic chrysophyte Ochromonas sp. Ecology, 77, 706-715.

Rothhaupt K.O. (1996b) Laboratory experiments with a mixotrophic chrysophyte and obligately phagotrophic and phototrophic competitors. Ecology, 77, 716-724.

Sierszen M.E. \& Frost T.M. (1992) Selectivity in suspension-feeders: food quality and the cost of being selective. Archiv für Hydrobiologie, 123, 257-273.

Smalley G.W., Coats D.W. \& Adam E.J. (1999) A new method using fluorescent microspheres to determine grazing on ciliates by the mixotrophic dinoflagellate Ceratium furca. Aquatic Microbial Ecology, 17, 167-179.

Stoecker D.K. (1988) Are marine planktonic ciliates suspension-feeders? Journal of Protozoology, 35, 252255.

Stoecker D.K. (1991) Mixotrophy in marine planktonic ciliates: physiological and ecological aspects of plastid retention by oligotrichs. In: Protozoa And Their Role In Marine Processes (eds P.C. Reid, C.M. Turley \& P.H. Burkill), pp. 161-180. Springer-Verlag, Berlin.

Stoecker D.K. (1992) Chloroplast-retention in ciliated protozoa. In: Origins of Plastids (ed. R. A. Lewin), pp. 9-26. Chapman \& Hall, New York, NY.

Stoecker D.K. (1998) Conceptual models of mixotrophy in planktonic protists and some ecological and evolutionary implications. European Journal of Protistology, 34, 281-290.

Stoecker D.K. (1999) Mixotrophy among dinoflagellates. Journal of Eukaryotic Microbiology, 46, 397-401.

Stoecker D.K. \& Michaels A.E. (1991) Respiration, photosynthesis and carbon metabolism in planktonic ciliates. Marine Biology, 108, 44-447. 
Stoecker D.K. \& Silver M.W. (1990) Replacement and aging of chloroplasts in Strombidium capitatum (Ciliophora: Oligotrichida). Marine Biology, 107, 491502.

Stoecker D.K., Michaels A.E. \& Davis L.H. (1987) Large proportion of marine planktonic ciliates found to contain functional chloroplasts. Nature, 326, 790-792.

Stoecker D.K., Silver M.W., Michaels A.E \& Davis L. H. (1988a) Obligate mixotrophy in Laboea strobila, a ciliate which retains chloroplasts. Marine Biology, 99, 415-423.

Stoecker D.K., Silver M.W., Michaels A.E \& Davis L. H. (1988b) Enslavement of algal chloroplasts by four Strombidium spp. Marine Microbial Food Webs, 3, 79-100.

Stoecker D.K., Taniguchi A. \& Michaels A.E. (1989) Abundance of autotrophic, mixotrophic and heterotrophic planktonic ciliates in shelf and slope waters. Marine Ecology Progress Series, 50, 241-254.

Stoecker D.K., Putt M., Davies L.H. \& Michaels A.E. (1991) Photosynthesis in Mesodinium rubrum: species-specific measurements and comparison to community rates. Marine Ecology Progress Series, 73, 245-252.

Stoecker D.K., Sieracki M.E., Verity P.G., Michaels A.E., Haugen E., Burkill P.H. \& Edwards E.S. (1994) Nanoplankton and protozoan microzooplankton during the JGOFS North Atlantic Bloom Experiment: 1989 and 1990. Journal of the Marine Biological Association U.K., 74, 427-443.
Stoecker D.K., Gustafson D.E. \& Verity P.G. (1996) Micro- and mesoprotozooplankton at $140^{\circ} \mathrm{W}$ in the equatorial Pacific: heterotrophs and mixotrophs. Aquatic Micobial Ecology, 10, 273-282.

Suzuki T., Yamada N. \& Taniguchi A. (1998) Standing crops of planktonic ciliates and nanoplankton in oceanic waters of the western Pacific. Aquatic Microbial Ecology, 14, 49-58.

Swanberg N.R. \& Caron D.A. (1991) Patterns of sarcodine feeding in epipelagic oceanic plankton. Journal of Plankton Research, 13, 287-312.

Thingstad T.F. (1996) On the strategy of 'eating your competitor': a mathematical analysis of algal mixotrophy. Ecology, 77, 2108-2118.

Thingstad T.F., Pérez M.T., Pelegri S., Dolan J.R. \& Rassoulzadegan F. (1999) Trophic control of bacterial growth in microcosms containing a natural community from northwest Mediterrean surface waters. Aquatic Microbial Ecology, 18, 145-156.

Vaqué D., Blough H.A. \& Duarte C.M. (1997) Dynamics of ciliate abundance, biomass and community composition in an oligotrophic coastal environment (NW Mediterranean). Aquatic Microbial Ecology, 12, 71-83.

Verity P.G. (1991a) Feeding patterns in planktonic protozoa: evidence for non-random aquisition of prey. Journal of Protozoology, 38, 939-946.

Verity P.G. (1991b) Aggregation patterns of ciliates from natural assemblages in response to different prey. Marine Microbial Food Webs, 5, 115-128.

(Manuscript accepted 5 June 2000) 